\title{
Characterization of Secondary Metabolites in Two Cousinia species
}

\author{
Leyla Paşayeva (D)*,1, Hanifa Fatullayev (iD) 2, İrem Nur Karakuş ${ }^{1}$, Serap Soylu ${ }^{1}$, \\ Osman Tugay 3 \\ ${ }^{1}$ Department of Pharmacognosy, Faculty of Pharmacy, Erciyes University, Kayseri, Turkey \\ ${ }^{1}$ Department of Pharmaceutical Chemistry, Faculty of Pharmacy, Erciyes University, Kayseri, Turkey \\ ${ }^{1}$ Department of Pharmaceutical Botany, Faculty of Pharmacy, Selcuk University, Konya, Turkey
}

\begin{abstract}
Cousinia is one of the widespread genera of Asteraceae family. According to previous studies on some Cousinia species it was found that these species are rich of triterpenes, sesquiterpenes, flavonoids, acetylenes and steroids. According to our knowledge, there are no published reports on the chemical composition of $C$. iconica Hub. - Mor. and C. aintabensis Boiss. $\&$ Hausskn., thus we aimed to investigate secondary metabolites of these species. In this study, the phytochemical constituents of these species were evaluated. Seven of identified compounds were quantified. The quantitative and qualitative determination of compounds within the extracts was carried out by LC-MS/MS. Phytochemical analyses revealed the presence of flavonoids, saponins, terpenes and steroids. Preliminary examination of the mass spectrums revealed the presence of phenolic acids and derivatives and flavonoid compounds in extracts. According to quantitative analyses the main compound of $C$. iconica $(\mathrm{CI})$ and $C$. aintabensis $(\mathrm{CA})$ extracts was rutin with the highest contents $\left(169.779 \mu \mathrm{g} / \mathrm{mg}_{\text {extract }}\right.$ and $161.638 \mu \mathrm{g} / \mathrm{mg}_{\text {extract }}$ ). Moreover, qualitative and quantitative study combined with different biological activities will shed new lights to the advanced studies.
\end{abstract}

\section{ARTICLE HISTORY}

Received: July 21, 2019

Revised: November 16, 2019

Accepted: December 23, 2019

\section{KEYWORDS}

Cousinia,

Asteraceae,

LC-MS/MS,

Rutin,

Flavonoid

\section{INTRODUCTION}

Cousinia Cass. is one of the widespread genera of Asteraceae family with 600-700 species distributed in Central and South-West Asia. There are 39 species and 6 sections of Cousinia genus in Turkey [1]. In the literature, taxonomic and systematic studies are generally performed on the genus of Cousinia, but phytochemical and activity studies are rarely seen. Numerous studies have shown that plants of the genus are rich in triterpenes, sesquiterpenes, flavonoids, acetylenes and steroids [2-8]. In phytochemical studies it was reported isolation of guianolide type sesquiterpenes from Cousina picheriana Bornm. ex Rech.f., C. piptocephala Bunge. and C. canescens DC. [2], oxygenated bisabolene derivatives from C. canescens DC., phenolic and triterpenic compounds from $C$. adenostica Bornm., C. aitchisonii Boiss. [5, 9-12] and fatty acids from $C$. aurea C.Winkl., $C$. seversovii Regel, $C$. umbrosa Bunge. [13, 14]. In a study, ethanol extracts from different Cousinia species were subjected to cytotoxic screening on the fibrocarcinoma cell line. The highest activity was observed in C. verbascifolia Bunge. $\left(\mathrm{IC}_{50}=\right.$

CONTACT: Leyla Paşayeva $₫$ leylapasayeva@erciyes.edu.tr $\equiv$ Department of Pharmacognosy, Faculty of Pharmacy, Erciyes University, Kayseri, Turkey 
$18.4 \pm 0.59 \mu \mathrm{g} / \mathrm{mL})[15]$. According to Iranshahy et al. sesquiterpene compounds namely desoxyjanerin and raserolit obtained from the dichloromethane extract of $C$. aitchisonii were subjected cytotoxic screening on five different cell lines. As a result, both compounds showed significant cytotoxic effect on breast cancer MCF-7 cell line $\left(\mathrm{IC}_{50}=4.5 \mu \mathrm{g} / \mathrm{mL}\right.$ and $4.6 \mu \mathrm{g} /$ $\mathrm{mL}$, respectively) [10]. In another study MMP inhibitor effect of $C$. shulabadensis Attar \& Ghahr. was investigated and reported to have a considerable inhibitory effect $\left(\mathrm{IC}_{50}=49.2 \pm\right.$ $0.51 \mu \mathrm{g} / \mathrm{mL}$ ) [16]. In a study by Shahverdi et al. the antibacterial effects of ethanol extracts of seven different Cousinia species was investigated by disk diffusion method in different Gram (+) and Gram (-) strains and the highest effect was determined in C. phyllocephala Bornm. \& Gauba extract against Staphylococcus aereus and Bacillus subtilis (MIC $=4 \mathrm{mg} / \mathrm{disc}$ ) [15]. Cousinia iconica Hub.- Mor. from Cousinia section is endemic to Turkey and distributed in open areas, scrublands and stony slopes. Cousinia aintabesis Boiss. \& Hausskn. is a perennial herb with purple flowers from Cynaroidae Bunge. section [1]. Because a few studies were reported on these species we aimed to investigate the phytochemical properties of these species. In this study, phytochemical profile of methanol extracts and quantitative analyses of determined compounds were quantified.

\section{MATERIAL and METHODS}

\subsection{Chemicals}

All chemicals, standarts and reagents were analytical or HPLC grade and purchased from Sigma-Aldrich.

\subsection{Plant material and preparation of extracts}

The flowering aerial parts of $C$. iconica was collected from Konya and $C$. aintabensis from Mardin in July 2013. The voucher specimens were deposited at the Herbarium unit of the Science Faculty, Selcuk University, Konya, Turkey (Voucher No. 1, KNYA 11.040; Voucher No. 2, KNYA 77.81 respectively). Air dried aerial parts of $C$. iconica $(500 \mathrm{~g})$ and $C$. aintabensis $(500 \mathrm{~g})$ were powdered and extracted three times with methanol by maceration, at room temperature. Combined macerates filtered and evaporated to dryness under reduced pressure at $37^{\circ} \mathrm{C}$ using a rotary evaporator. The crude extracts were stored in a dark at $-20^{\circ} \mathrm{C}$. Yields of methanol extracts of CA and CI were $\% 10$ and $\% 15$ respectively.

\subsection{Preliminary phytochemical analysis}

The secondary metobilites of CA and CI extracts were evaluated by following standard methods [17-19].

\subsubsection{Test for carbohydrates}

Fehling's test: $2 \mathrm{~mL}$ of Fehling A and $2 \mathrm{~mL}$ of Fehling B was added to $1 \mathrm{~mL}$ of test solution in a test tube and carefully heated in a water bath. Precipitation of red $\mathrm{Cu}_{2} \mathrm{O}$ indicated the presence of reducing sugars.

Benedict's test: $1 \mathrm{~mL}$ of test solution was taken in a test tube and $2 \mathrm{~mL}$ of Benedict's reagent was added to test solution. The mixture was boiled, and a reddish-brown precipitate was occurred. This result indicated the presence of the carbohydrates.

\subsubsection{Test for flavonoids (Shinoda test)}

The crude extract was taken in a capsule and $5 \mathrm{~mL}$ of a mixture of ethanolic hydrochloric acid (ethanol-HCl-water 1: 1: 1 v / v) was added. Finally, 5-6 magnesium ribbon was added in this mixture. Appeared Pink scarlet color indicated the presence of flavonoids. 


\subsubsection{Test for saponins}

Crude extract was shaked with $5 \mathrm{~mL}$ of distilled water in a test tube. The formation of stable foam was indicated the presence of saponins. Liebermann's test: Crude extract which mixed about $2 \mathrm{~mL}$ of chloroform is evaporated to dryness on a water bath in a porcelain capsule. Then the residue was dissolved by the addition of $1 \mathrm{~mL}$ of glacial acetic acid. About 1-2 $\mathrm{mL}$ of concentrated $\mathrm{H}_{2} \mathrm{SO}_{4}$ carefully added. A color change from violet to blue to green represented the presence of steroidal saponins.

Salkowski's test: For preparation test solution crude extract was mixed with $2 \mathrm{~mL}$ of chloroform. Then about $2 \mathrm{~mL}$ of concentrated $\mathrm{H}_{2} \mathrm{SO}_{4}$ was added and shaken gently. A reddish brown colour remarked the presence of steroidal ring.

\subsubsection{Cardiac glycosides}

Keller-Killiani test: Crude extract was dissolved in $2 \mathrm{~mL}$ of glacial acetic acid (containing 1-2 drops of $2 \% \mathrm{FeCl}_{3}$ solution. Then $2 \mathrm{~mL}$ of concentrated $\mathrm{H}_{2} \mathrm{SO}_{4}$ was added. a brown ring at the interphase indicated the presence of cardiac glycosides. Baljet test: Crude extract was dissolved with chloroform ethanol mixture (4:1). Following this sodium picrate reagent and 2 drops of $20 \% \mathrm{NaOH}$ was added to mixture. If cardiac aglycon is present yellow to orange color will be seen.

Kedde test: Crude extract is treated with a small amount of Kedde reagent (Mix equal volumes of a $2 \%$ solution of 3,5-dinitrobenzoic acid in menthol and a 7.5\% aqueous solution of $\mathrm{KOH}$ ) and 2 drops of $20 \% \mathrm{NaOH}$ solution. Development of a blue or violet color showed presence of cardiac aglycon.

\subsubsection{Test for alkaloids}

Crude extract was mixed with $2 \mathrm{~mL}$ of $1 \% \mathrm{HCl}$ and heated gently. Then reagents of Mayer and Wagner were added to the test solution. Turbidity of the resulting precipitate was showed the presence of alkaloids.

\subsubsection{Test for tannins}

Crude extract was boiled with $20 \mathrm{~mL}$ distilled water for $5 \mathrm{~min}$ and filtered while hot. Then $1 \mathrm{ml}$ of cool filtrate was diluted to $5 \mathrm{~mL}$ with distilled water and a few drops (2-3) of $10 \%$ ferric chloride were added and observed for the formation of precipitates and any color change. A bluish-black or brownish-green precipitate indicated the presence of tannins.

\subsubsection{Test for combined anthraquinones}

Powdered sample $(1 \mathrm{~g})$ was boiled with $2 \mathrm{~mL}$ of $10 \%$ hydrochloric acid for $5 \mathrm{~min}$. Then the mixture was filtered while hot, cooled and partitioned with the equal volume of chloroform. The chloroform layer was taken into test tube and an equal volume of $10 \%$ ammonia solution was added, shaken and allowed to separate. Rose pink color in separated aqueous layer indicated the presence of anthraquinones.

\subsection{Qualitative and Quantitative LC-MS/MS Assay}

Compounds in CA and $\mathrm{CI}$ extracts were determined qualitative and quantitative by using liquid chromatography-electrospray ionization-mass spectrometry/ mass spectrometry (LCESI-MS/MS, Shimadzu 8040). The liquid chromatograph was a Shimadzu (Kyoto, Japan) Nexera XR system with an SIL-20AC autosampler, an LC-20AD high-pressure gradient pump system (20- $\mu$ L mixer), a DGU-20A3R vacuum degasser, and a CTO-10AS VP column oven. Mass spectrometry was conducted using a Shimadzu LCMS-8040 triple quadrupole mass spectrometer equipped with an electrospray ionization (ESI) interface in the negative-ion mode. 
The following instrument settings were used for analysis: column Restek (150 x $4.6 \mathrm{~mm}$ x $3 \mu \mathrm{m}$ ); column heat, $40^{\circ} \mathrm{C}$; heat block temperature, $400{ }^{\circ} \mathrm{C}$; DL temperature, $250{ }^{\circ} \mathrm{C}$; nebulizing gas $\left(\mathrm{N}_{2}\right), 3 \mathrm{~L} / \mathrm{min}$; drying gas $(\mathrm{N} 2), 15 \mathrm{~L} / \mathrm{min}$; collision energy, 25.0, 12.0, 9; dwell time, $100 \mathrm{msec}$. A mixture of methanol: formic acid (99:1 v/v) (A) and water: formic acid (99:1, $\mathrm{v} / \mathrm{v}$ ) (B) was selected as the mobile phase. The mobile phase consisted of $50 \%$ solvent $\mathrm{A}$ and $50 \%$ solvent $\mathrm{B}$ at a flow rate of $0,4 \mathrm{~mL} / \mathrm{min}$, and injection volume was $1 \mu \mathrm{L}$.

\section{RESULTS and DISCUSSION}

\subsection{Preliminary phytochemical analysis}

The phytochemical characteristics of two extracts were summarized in the Table 1. From the results, it was found that, carbohydrates, flavonoids, steroids and saponins were present, but alkaloids, anthraquinones and cardiac glycosides were absent in the plant extracts. Although, tannins were not detected in CI extract, but CA extract showed positive result for this secondary metabolite. The preliminary phytochemical tests are helpful in finding chemical constituents in the plant material that may lead to their quantitative estimation and also in locating the source of pharmacologically active chemical compound.

Table 1. Phytochemical constituents of extracts

\begin{tabular}{|c|c|c|c|}
\hline Phytochemical & Type of test & C. iconiensis & C. aintabensis \\
\hline Carbohydrates & Fehling & + & + \\
\hline Alkaloids & Benedict & + & + \\
\hline Cardiac glycosides & Mayer & - & - \\
\hline Saponins & Wagner & - & - \\
\hline Flavonoids & Keller-Kiliani & - & - \\
\hline Tannins & Baljet & + & + \\
\hline Anthraquinones & Kedde & + & + \\
\hline
\end{tabular}

"- " the result of the test is negative, "+" the result of the test is positive

\subsection{Qualitative analysis of chemical compounds}

The identification of chemical compounds in methanol extracts was evaluated on the basis of the accurate mass, the registered mass spectra fragmentation patterns and literature data. The mass spectrometric behavior of the compounds was studied using both positive-ion, and negative-ion mode. But negative-ion mode provided a better sensitivity than the other for these compounds due to more efficient ionization, simpler fragmentation, and lower baseline noise. Total ion chromatograms (TIC) of extracts were shown in Figure 1. The mass spectrums of extracts revealed the presence of 3 phenolic acids (vanilic acid, chlorogenic acid and caffeic acid), 2 organic acids (quinic acid and malic acid) and 2 flavonoid (rutin and isorhamnetin 3$O$-rutinoside) compounds in methanol extract of $C$. iconica and $C$. aintabensis (Table 2). The mass spectra of extracts were shown in Figure 2.

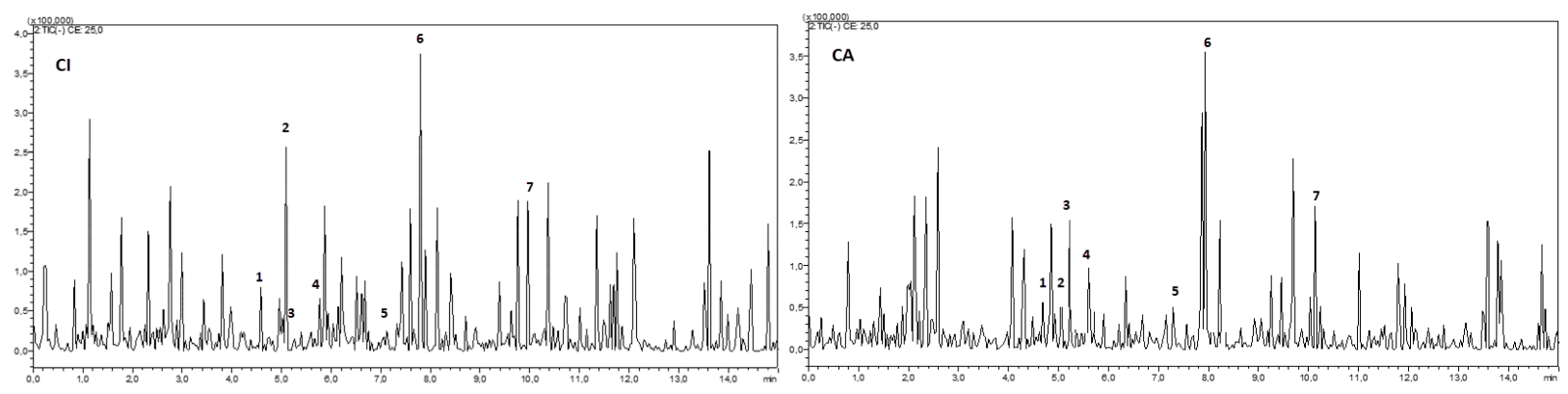

Figure 1. TIC profile of extracts. CI- methanol extract of $C$. iconiensis, CA- methanol extract of $C$. aintabensis. 
Table 2. Phytochemical constituents of extracts

\begin{tabular}{llccc}
\hline $\begin{array}{l}\text { Peak } \\
\text { No }\end{array}$ & $\begin{array}{l}\text { RT } \\
(\min )\end{array}$ & $\begin{array}{c}{[\mathrm{M}-\mathrm{H}]^{-}} \\
(\mathrm{m} / \mathrm{z})\end{array}$ & $\begin{array}{c}\text { MS/MS } \\
(\mathrm{m} / \mathrm{z})\end{array}$ & Compounds \\
\hline 1 & 4.6 & 167 & 123,152 & Vanilic acid [31] \\
2 & 5.1 & 353 & $191,179,173,135$ & $\begin{array}{c}\text { Chlorogenic acid } \\
{[32]}\end{array}$ \\
3 & 5.2 & 191 & $191,108,93$ & Quinic acid [33] \\
4 & 5.6 & 179 & $135,179,87$ & Caffeic acid [34] \\
5 & 7.2 & 133 & $133,115,71$ & Malic acid [35] \\
6 & 8 & 609 & 300,301 & Rutin [36] \\
7 & 10.2 & 623 & $285,300,315$ & Isorhamnetin 3-O- \\
& & & & \\
\hline
\end{tabular}

RT: Retention Time

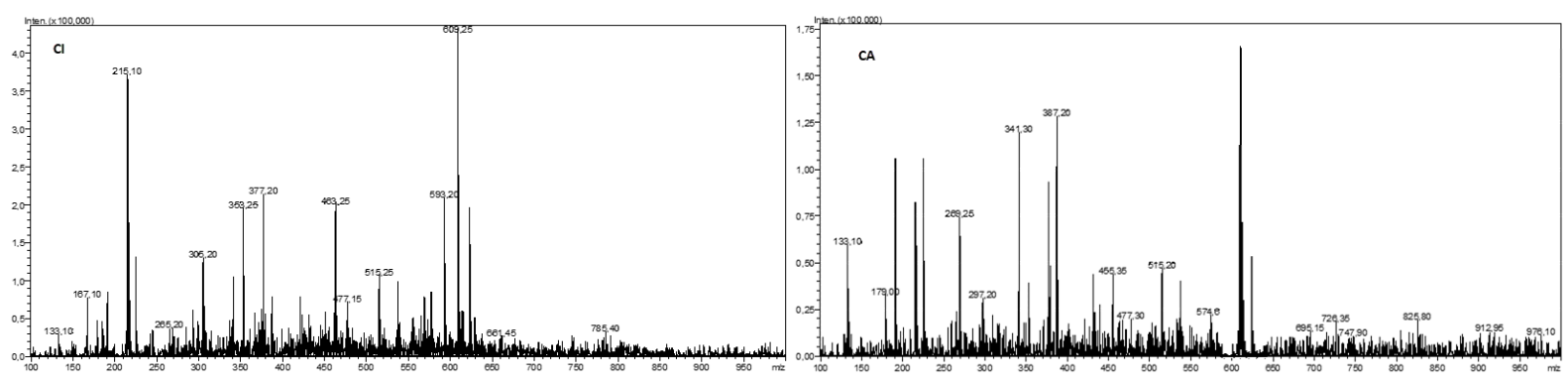

Figure 2. TIC profile of extracts. CI- methanol extract of $C$. iconiensis, CA- methanol extract of $C$. aintabensis

\subsection{Quantitative Analyses of Compounds}

\subsubsection{Optimisation of LC-MS/MS Condition}

The mass spectrometric behavior of compounds was studied using both positive-ion and negative-ion mode. Negative-ion mode provided a better sensitivity for these compounds due to more efficient ionization, simpler fragmentation, and lower baseline noise. These compounds were subsequently analyzed in Q1Scan (Product Ion Scan) mode, using $[\mathrm{M}-\mathrm{H}]^{-}$ions as precursors. Obtained $\mathrm{MS}^{2}$ spectras were used to select the optimal product ions. The MRM parameters, such as the precursor ion $\mathrm{m} / \mathrm{z}$, collision energy, and product ion $\mathrm{m} / \mathrm{z}$ for compounds were optimized by an automatic MRM optimization function. For malic acid, due to the loss of water $\left[\mathrm{M}-\mathrm{H}-\mathrm{H}_{2} \mathrm{O}\right]^{-}$providing an ion at $\mathrm{m} / \mathrm{z} 115$ and with the loss of $\mathrm{CO}_{2}$ an intense ion at $\mathrm{m} / \mathrm{z}$ 71 [20]. The peak identified as a chlorogenic acid ( $\mathrm{m} / \mathrm{z} 353)$, produced to the loss of one of the caffeoyl moieties [M-H-caffeoyl] ${ }^{-}$, and subsequent fragmentation of ion yielded the fragments at $\mathrm{m} / \mathrm{z} 191$ (deprotonated quinic acid), 179 [caffeic acid-H] ${ }^{-}, 135$ and the peak of the ion at $\mathrm{m} / \mathrm{z}$ 173 (the absence of a $\mathrm{C} 4$ substituent) [21]. Fragmentation of $[\mathrm{M}-\mathrm{H}]^{-}$ion $(\mathrm{m} / \mathrm{z} 609)$ of rutin resulted in two major ions at $\mathrm{m} / \mathrm{z} 300$ and 301, showing the loss of rhamnose-glucose unit. The other flavonol diglycoside isorhamnetin 3-O-rutinoside is a 3'-methoxylated derivative of rutin. Fragmentation of this molecule $[\mathrm{M}-\mathrm{H}]^{-}$ion $(\mathrm{m} / \mathrm{z} 623)$ resulted ions $\mathrm{m} / \mathrm{z} 285,300$ and 315. Isorhamnetin represents specific fragmentation with the loss of $\mathrm{CH}_{3}$ radical from the deprotonated aglycone, thus giving $\mathrm{m} / \mathrm{z} 315 \rightarrow \mathrm{m} / \mathrm{z} 300$ and the $\mathrm{m} / \mathrm{z} 285$ pattern as a result of fragmentation in C-ring [22]. With the loss of $\mathrm{CO}_{2}$ providing an intense ion at $\mathrm{m} / \mathrm{z} 123$ for vanilic acid [23]. The obtained LC-MS/MS chromatogram and mass spectrum of compounds are presented in Figure 3. 


\subsubsection{Preparation of Standard and Sample Solutions}

Stock solutions of compounds were prepared in methanol at $8 \mu \mathrm{g} / \mathrm{mL}$ concentrations. The extracts solutions were prepared in methanol at $10 \mu \mathrm{g} / \mathrm{mL}$.

\subsubsection{Calibration Curve}

Linearity of the methods was established by triplicate injections of each concentration of standard solutions. Response function of the standards calibration curve was $y=10074 \mathrm{x}+$ 994.36 for malic acid, $y=33716 x-2152.2$ for chlorogenic acid, $y=16535 x+275.47$ for quinic acid, $\mathrm{y}=181197 \mathrm{x}+9999$ for caffeic acid, $\mathrm{y}=511143 \mathrm{x}-4056$ for rutin and $\mathrm{y}=18006 \mathrm{x}+$ 928.47 for isorhamnetin 3-O-rutinoside and $\mathrm{y}=8656.4 \mathrm{x}+184.21$ for vanilic acid. The correlation coefficient $\left(\mathrm{r}^{2}\right)$ of the calibration curves was $0.9988,0.9995,0.9994,0.9991,0.9997$, 0.9996 and 0.9991 respectively. The quantitative results of compounds are given in Table 3. As shown in table, the main compounds in CI extracts were rutin $\left(169.779 \mu \mathrm{g} / \mathrm{mg}_{\text {extract }}\right)$ and chlorogenic acid $\left(26.051 \mu \mathrm{g} / \mathrm{mg}_{\text {extract }}\right)$. But, the main compounds in CA were rutin $(161.638$ $\mu \mathrm{g} / \mathrm{mg}_{\text {extract }}$ ), quinic acid (37.715 $\mu \mathrm{g} / \mathrm{mg}_{\text {extract }}$ ), and isorhamnetin 3-O-rutinoside (37.273 $\left.\mu \mathrm{g} / \mathrm{mg}_{\mathrm{extract}}\right)$.

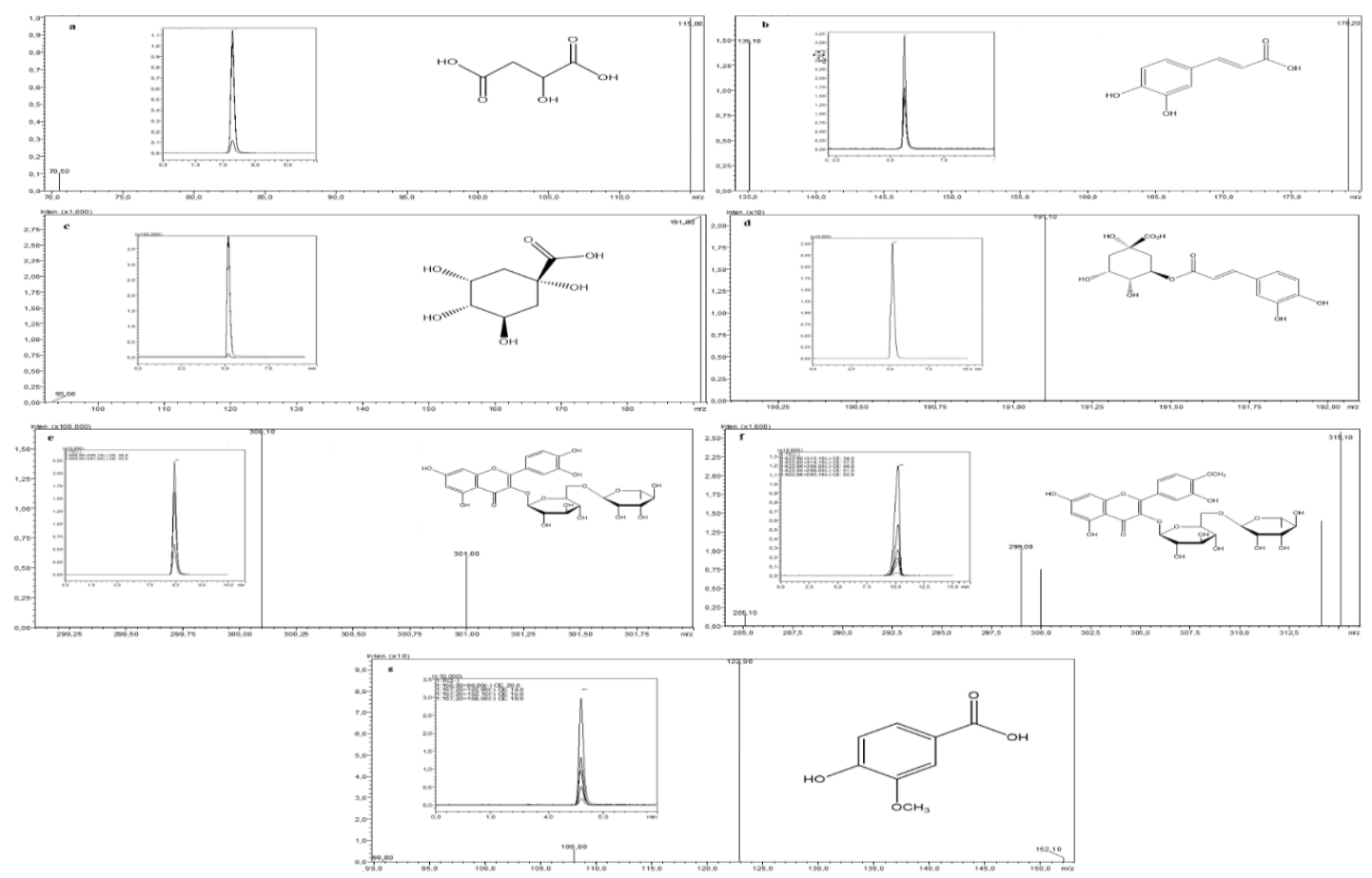

Figure 3. LC-MS/MS chromatogram and mass spectra of malic acid (a), caffeic acid (b), quinic acid (c), chlorogenic acid (d), rutin (e), isorhamnetin 3-O-rutinoside (f) and vanilic acid (g)

Table 3. Contents of compounds in extracts $\left(\mu \mathrm{g} / \mathrm{g}_{\text {extract }} \pm \mathrm{SD}\right)$.

\begin{tabular}{lccc}
\hline Constituent & RT $(\mathrm{min})$ & $\mathrm{C}$ & Content $^{\mathrm{a}}(\mu g / m g$ \\
extract
\end{tabular}

RT-retention time. ${ }^{a}$ Mean \pm SD $(n=3)$. CI- methanol extract of $C$. iconiensis, CA- methanol extract of $C$. aintabensis 
To date, sesquiterpene lactones (C. picheriana, $C$. piptocephala, $C$. canescens), triterpenes $(C$. adenostica), steroids $(C$. canescens) and flavonoids $(C$. verbascifolia $)$ have been isolated from Cousinia genus [2-8, 24]. In the present study the preliminary qualitative analysis of secondery metobilities in $C$. iconica and $C$. aintabensis revealed the presence of carbohydrates, flavonoids, tannins, saponins and steroids which have a wide range of cytotoxic and antitumor effects. Moreover, phenolic acids, organic acids and flavonoid compounds were identified in these species by LC-MS/MS. For the first time vanilic acid, chlorogenic acid, quinic acid, caffeic acid, malic acid, rutin and isorhamnetin 3-O-rutinoside were detected and quantified in these two species. In a result, rutin was found to be the most abundant among the compounds and about $10 \%$ of two methanol extract. Some of these detected chemical compounds display a remarkable spectrum of biological activities including antidiabetic [25], antiulcer and antioxidant [26], anti-inflammatory [27], cytotoxic, anticarcinogenic [28], antispasmodic [29] and antidepressant [30]. Moreover, qualitative and quantitative study combined with this activities evaluation will shed new lights to the advanced studies.

\section{CONCLUSION}

This is the first report on the phytochemical characterization of these species from Cousinia genus. Moreover, it was thought that chemical compounds identified in this genus could represent a chemical marker of the Cousinia genus as contributing to the chemotaxonomy.

\section{Acknowledgements}

The authors are grateful to the Erciyes University Scientific Research Projects Coordinating Unit (BAP, project number THD-2018-7921) for financial support and Erciyes University Ziya Eren Drug Application and Research Center (ERFARMA) for providing LC-MS/MS facility.

\section{Orcid}

Leyla Paşayeva (D) https://orcid.org/0000-0003-3860-7222

Hanifa Fatullayev (Di) https://orcid.org/0000-0002-7123-8396

İrem Nur Karakuş (iD https://orcid.org/0000-0003-3980-7648

\section{REFERENCES}

[1]. Davis, P.H., Huber, A.M. (1975). Cousinia in Flora of Turkey and the East Aegean Islands. Edinburgh University Press, Edinburgh.

[2]. Marco, J.A., Sanz, J.F., Albiach, R., Rustaiyan, A., Habibi, Z. (1993). Bisabolene derivatives and sesquiterpene lactones from Cousinia species. Phytochemistry, 32, 395400.

[3]. Plekhanova, N., Turdumambetov, K., Sudnitsyna, I. (1983). Carbohydrates of Cousinia. Khim Prir Soedin, 19, 603-604.

[4]. Rustaiyan, A., Niknejad, A., Sigari, H., Ahmadi, A. (1981). Guaianolides from Cousinia onopordioides. Fitoterapia, 52, 31-32.

[5]. Rustaiyan, A., Sharif, Z., Sadjadi, A.S. (1987). Two farnesol derivatives from Cousinia adenostica. Phytochemistry, 26,2635-2636.

[6]. Turdumambetov, K., Plekhanova, N., Rakhimov, D., Yagudaev, M. (1989). Glucofructans of Cousinia polycephala. Khim Prir Soedin, 25, 371-372.

[7]. Turdumambetov, K., Rakhimov, D., Malikova, M.K. (2007). Oligo-and polysaccharides from Cousinia umbrosa. Khim Prir Soedin, 43,308-309.

[8]. Ulubelen, A., Tuzlaci, E., Mericli, A. (1986). Triterpenic and steroidal compounds from Cousinia canescens. Fitoterapia, 57, 269-270. 
[9]. González, A.G., Bermejo, J., Amaro, J.M., Massanet, G.M., Galindo, A., Cabrera, I. (1978). Sesquiterpene lactones from Centaurea linifolia Vahl. Canadian Journal of Chemistry, 56, 491-494.

[10]. Iranshahy, M., Tayarani-Najaran, Z., Kasaian, J., Ghandadi, M., Emami, S.A., Asili, J., Chandran, J.N., Schneider, B., Iranshahi, M. (2016). Highly Oxygenated Sesquiterpene Lactones from Cousinia aitchisonii and their Cytotoxic Properties: Rhaserolide Induces Apoptosis in Human T Lymphocyte (Jurkat) Cells via the Activation of c-Jun n-terminal Kinase Phosphorylation. Phytotherapy research, 30, 222-226.

[11]. Seaman, F.C. (1982). Sesquiterpene lactones as taxonomic characters in the Asteraceae. Bot Rev, 48, 121-594.

[12]. Suchý, M., Herout, V., Šorm, F. (1960). On terpenes. CVI. On hydrogenation products of cynaropicrin, the bitter principle of artichoke (Cynara scolymus L.). Collection of Czechoslovak Chemical Communications, 25, 507-514.

[13]. Ul'chenko, N., Gigienova, E., Umarov, A., Isamukhamedov, A.S. (1981). Hydroxy acids of the seed oils of five plants of the family Asteraceae. Khim Prir Soedin, 17, 26-30.

[14]. Ul'chenko, N., Mukhamedova, K.S., Glushenkova, A. (1999). Lipids from seeds of two species of Cousinia. Khim Prir Soedin, 35, 680-681.

[15]. Shahverdi, A.R., Khorramizadeh, M.R., Attar, F., Saadat, F., Vahid, S., Ghahraman, A. (2007). Concomitant chemopreventive and antibacterial effects of some Iranian plants from the genus Cousinia (Asteraceae). Revista Brasileira de Farmacognosia, 17, 325330.

[16]. Shahverdi, A.R., Khoramizadeh, M.R., Ghahramani, M.H., Golyaee, A., Attar, F., Ghahraman, A. (2007). Chemopreventive Effect of Cousinia shulabadensis Attar \& Ghahraman ethanol extract. Afr J Tradit Complem, 4, 12-16.

[17]. Evans, W.C. (2009). Trease and evans' pharmacognosy E-book. 16th ed.; Elsevier Health Sciences: 319-330; ISBN 978-0-7020-2934-9.

[18]. Harborne, J. (1984). Methods of plant analysis. Phytochemical methods, 2nd ed.; Academic Press: 1-36.

[19]. Yadav, R., Agarwala, M. (2011). Phytochemical analysis of some medicinal plants. Journal of phytology, 3(12), 10-14.

[20]. Fernández-Fernández R., López-Martínez J.C., Romero-González R., Martínez-Vidal J.L., Flores M.I.A., Frenich A.G. (2010). Simple LC-MS determination of citric and malic acids in fruits and vegetables. Chromatographia, 72, 55-62.

[21]. Barros, L., Dueñas, M., Carvalho, A.M., Ferreira, I.C., Santos-Buelga, C. (2012). Characterization of phenolic compounds in flowers of wild medicinal plants from Northeastern Portugal. Food and Chemical Toxicology, 50, 1576-1582.

[22]. Martucci, M.E.P., De Vos, R.C., Carollo, C.A., Gobbo-Neto, L. (2014). Metabolomics as a potential chemotaxonomical tool: application in the genus Vernonia Schreb. PLoS One 9:e93149

[23]. Prasain, J.K., Wang, C.-C., Barnes, S. (2004). Mass spectrometric methods for the determination of flavonoids in biological samples. Free Radical Biology and Medicine, 37, 1324-1350.

[24]. Ulubelen, A., Tuzlac1, E. (1988). Flavonoids and terpenoids from Cousinia eriosephala. Fitoterapia, 59, 350.

[25]. Thorne, S.E., Paterson, B.L. (2001). Health care professional support for self-care management in chronic illness: insights from diabetes research. Patient education and counseling, 42,81-90.

[26]. Ghasemzadeh, A., Ghasemzadeh, N. (2011). Flavonoids and phenolic acids: Role and biochemical activity in plants and human. Journal of medicinal plants research, 5, 66976703. 
[27]. Araujo, C., Leon, L. (2001). Biological activities of Curcuma longa L. Memórias do Instituto Oswaldo Cruz, 96, 723-728.

[28]. Murakami, M., Yamaguchi, T., Takamura, H., Atoba, T. (2004). Effects of thermal treatment on radical-scavenging activity of single and mixed polyphenolic compounds. Journal of food science, 69, FCT7-FCT10.

[29]. Ammon, H. P. T., Anazodo, M. I., Safayhi, H., Dhawan, B. N., \& Srimal, R. C. (1992). Curcumin: a potent inhibitor of leukotriene B4 formation in rat peritoneal polymorphonuclear neutrophils (PMNL). Planta medica, 58(02), 226-226.

[30]. Yu, L., Haley, S., Perret, J., Harris, M., Wilson, J., Qian, M. (2002). Free radical scavenging properties of wheat extracts. Journal of Agricultural and Food Chemistry, 50, 1619-1624.

[31]. Grieman, M. M., Greaves, J., \& Saltzman, E. S. (2015). A method for analysis of vanillic acid in polar ice cores.Climate of the Past, 11, 227-232.

[32]. Lin, L.-Z., He, X.-G., Lindenmaier, M., Nolan, G., Yang, J., Cleary, M., Qiu, S.-X., Cordell, G.A. (2000). Liquid chromatography-electrospray ionization mass spectrometry study of the flavonoids of the roots of Astragalus mongholicus and A. membranaceus. Journal of Chromatography A, 876, 87-95.

[33]. Clifford, M.N., Johnston, K.L., Knight, S., Kuhnert, N. (2003). Hierarchical scheme for LC-MS $\mathrm{n}$ identification of chlorogenic acids. Journal of agricultural and food chemistry, 51, 2900-2911.

[34]. Horai, H., Arita, M., Kanaya, S., Nihei, Y., Ikeda, T., Suwa, K., Ojima, Y., Tanaka, K., Tanaka, S., Aoshima, K. (2010). MassBank: a public repository for sharing mass spectral data for life sciences. Journal of mass spectrometry, 45, 703-714.

[35]. González, R.R., Fernández, R.F., Vidal, J.L.M., Frenich, A.G., Pérez, M.L.G. (2011). Development and validation of an ultra-high performance liquid chromatography-tandem mass-spectrometry (UHPLC-MS/MS) method for the simultaneous determination of neurotransmitters in rat brain samples. Journal of neuroscience methods, 198, 187-194.

[36]. Karaçelik, A.A., Küçük, M., İskefiyeli, Z., Aydemir, S., De Smet, S., Miserez, B., Sandra, P. (2015). Antioxidant components of Viburnum opulus L. determined by on-line HPLCUV-ABTS radical scavenging and LC-UV-ESI-MS methods. Food Chemistry, 175, 106114. 